\title{
Children's Perspectives on Their Learning in School Spaces: What Can We Learn from Children in Brazil and Finland?
}

\author{
Juliene Madureira Ferreira ${ }^{1}$ D $\cdot$ Kirsti Karila ${ }^{2}$ Luciana Muniz ${ }^{3}$. \\ Paula Faria Amaral ${ }^{3}$. Reijo Kupiainen ${ }^{4}$
}

Published online: 15 October 2018

(c) The Author(s) 2018

\begin{abstract}
In this study, we investigated children's perceptions of their learning experiences in early childhood education and care using data from two different settings: Brazil and Finland. We adopted a qualitative and cross-national research design. Photographs were used to gather children's representations of their learning places and spaces and also later to elicit reflections during group interviews. This process of using photographs allowed us to elicit children's perceptions about their learning. The analysis consisted of content categorization of the photographs, content analysis of the interviews, and juxtaposition of materials in a comparative framework. The children represented and conceived their learning experience in four categories of school spaces: objects, actions, significant others, and cultural practices. By analyzing each of these categories, we identify five core elements of children's perceptions about their learning: relevance of peer interactions; recognition of learning through play; children's acknowledgment of their own competence for learning; school spaces as places for learning actions; and present time as the timeframe for learning. Practical implications of these findings are discussed, including the importance and relevance of considering children's perceptions.
\end{abstract}

Keywords Learning spaces · Children's perceptions · Cultural practices · Multicultural research

\section{Résumé}

Dans cette étude, nous avons examiné les perceptions des enfants de leurs expériences d'apprentissage dans les services d'éducation et de garde de la petite enfance à l'aide de données provenant de deux milieux différents: le Brésil et la Finlande. Nous avons adopté un devis de recherche qualitatif et plurinational. Des photographies ont servi à recueillir les représentations des enfants de leurs espaces d'apprentissage et également, à un stade ultérieur, à susciter des réflexions chez les enfants lors d'entretiens

Juliene Madureira Ferreira

juliene.madureira.ferreira@uta.fi

Extended author information available on the last page of the article 
de groupe. Le processus d'utilisation de photographies nous a permis d'obtenir les perceptions des enfants de leur apprentissage. L'analyse consistait à catégoriser les photographies, analyser le contenu des entretiens et juxtaposer le matériel dans un cadre comparatif. Les enfants ont représenté leur expérience d'apprentissage dans quatre catégories d'espaces scolaires: les objets, les actions, les personnes significatives et les pratiques culturelles. En analysant ces catégories, nous avons identifié cinq éléments fondamentaux de la perception des enfants de leur apprentissage: la pertinence des interactions entre pairs, la reconnaissance de l'apprentissage par le jeu, la reconnaissance par les enfants de leur propre compétence d'apprentissage, les espaces scolaires comme lieux d'actions d'apprentissage, et le temps présent comme cadre temporel d'apprentissage. Les conséquences concrètes de ces résultats sont discutées, notamment l'importance et la pertinence des perceptions des enfants de leur propre apprentissage.

\section{Resumen}

Este estudio investigó las percepciones de niños sobre sus experiencias de aprendizaje en los primeros años de educación en la escuela y centros de cuidado infantil, utilizando datos producidos en dos contextos diferentes: Brasil y Finlandia. Se adoptó un diseño cualitativo y cruzado a nivel nacional. Se utilizaron fotografías para recolectar las representaciones de los niños de sus espacios de aprendizaje, y así mismo, para captar sus reflexiones durante entrevistas en grupo. El uso de fotografías permitió a los investigadores captar las percepciones de los niños sobre su aprendizaje. El análisis consistió en categorizaciones de fotografías, análisis del contenido de las entrevistas, y yuxtaposición de materiales en un marco comparativo. Los niños representaron sus experiencias de aprendizaje en cuatro categorías de espacios en la escuela: objetos, acciones, personas especiales y prácticas culturales. El análisis de estas categorías permitió la identificación de cinco elementos principales en las percepciones de los niños sobre su aprendizaje: importancia de sus interacciones con compañeros; reconocimiento del aprendizaje a través del juego; reconocimiento de los niños de sus propias competencias para el aprendizaje; espacios escolares como sitios de aprendizaje; y el ahora como marco temporal de aprendizaje. Este estudio también analiza las implicancias prácticas de estos hallazgos, incluyendo la importancia y relevancia de las percepciones de los niños acerca de su aprendizaje.

\section{Introduction}

Studies focused on exploring children's perspectives have gained prominence since the late 1990s. In general, such studies have identified children as important contributors to the investigation of their own reality. Listening to children's voices enables researchers to understand social phenomena with greater clarity (Sant'Ana 2010) and to access an entirely new world of meanings about the lives of children (Trautwein and Goncalves 2010; Pálmadóttir and Einarsdóttir 2016). Colliver and Fleer (2016) argued that understanding young children's perspectives can provide educators with concrete information to effectively guide their practices toward improving 
children's learning outcomes, as expected by contemporary curriculum frameworks across the globe.

Nevertheless, when it comes to defining learning and reflecting on its processes, younger children have been historically left out of this conversation. A substantial body of research argues that young children are incapable of understanding what learning is and reflecting on their own learning process. Metacognition is considered to be an ability that does not develop in children who are less than 4 years of age (Larkin 2010; Powell et al. 2011). Additionally, current studies in the field of early childhood education and care (ECEC) prefer to investigate learning by focusing on its outcomes, which are particularly linked to the effectiveness of educational programs or practices aimed at the acquisition of specific knowledge or skills (Burger 2015; Goodrich et al. 2017; Helal and Weil-Barais 2015; Landry et al. 2017). For such reasons, the focus on children's perspectives of their learning experiences is not a topic that has been extensively explored.

We consider it important to understand learning processes from the perspective of children. Similar to the significant advances that have been made to overcome the methodological challenges in children's participation in research (Clark 2005), we believe that efforts should be made to reduce the conceptual gaps between adults' acknowledgment of children's competence and understand children's perspectives about learning.

In this study, we address learning from the perspective of experience, which is defined by Larrosa (2002) as something that happens and transforms us. The learning experience is a process by which situations are able to influence the way we are constituted in a certain time (moment of life) and space. Therefore, a particular focus is given to how the contextual elements play a role in defining the learning experience. As learning can happen in different social contexts, time, and space, in this study, we clarify that we are interested in the learning experiences in ECEC context and in the school as a learning space.

We investigate children's perceptions of their learning experiences in the contexts of early childhood education (i.e., daycare centers or schools) by addressing the following research questions:

1. How do children perceive their learning experiences in ECEC settings? What ideas do children use to express what they understand of their own learning experiences?

2. What associations do children establish between their learning and the spaces in which they learn in ECEC contexts?

3. To what extent do cultural differences influence how children perceive their learning experiences in ECEC?

\section{School as a Learning Space}

To reflect on the idea of learning spaces in ECEC, we draw on Soja's (1996) concepts of Firstspace, Secondspace, and Thirdspace, which offer a more multidimensional and relational idea of space and point to an integration of human and 
environmental constituents. According to Soja (1996), space is not identified or defined solely by its material elements or geographical position; space has different dimensions, all directly related to culture, ideology, social rules, values, and human activity. Soja's interconnected dimensions of Firstspace (i.e., physical structures that compose the environment), Secondspace (i.e., personal meanings about the physical environment), and Thirdspace (i.e., cultural and social aspects that influence individual interpretations of space) are primal and connected to the individual. This understanding of space highlights how human action creates and defines space; at the same time, space provides affordances to certain actions in a dialectic process of constitution.

When we rely on these concepts of space to reflect on the learning experiences of children in ECEC, we recognize that children are a part of the construction of ECEC spaces and vice versa. Previous studies addressing children's perspectives of school space have focused on the use of physical space (Einarsdottir 2005), children's participation in the process of space construction (Vuorisalo et al. 2015), and children's agency in certain spaces or learning environments (Emilson and Folkesson 2004). Such studies have shown how adults and children relate to space jointly, and how children play an important role in defining the use of materials and physical spaces. The findings call for increased participation of children in the decisions that affect their school routine and the importance of considering peer relations in the context of ECEC. However, they do not address questions on how children live and understand their learning in the school space. Therefore, instead of examining the physical space, our aim is to focus specifically on the process of meaning making by which the experiences of learning are signified while in the school space. We aim to understand these experiences as the element that transforms the school in a learning space.

In line with the notion of Thirdspace, it is possible to focus on individual learning experiences and explore possibilities that a certain environment (in this case, ECEC) in different cultural settings offers for learning processes. In this sense, children's representations and perceptions of the school space reveal elements of their subjective and social life and experience, and these elements are part of how this experience is produced and negotiated in a shared process.

\section{Methods}

\section{Study Contexts: Brazil and Finland}

In Brazil, as in Finland, ECEC is recognized as a universal right of all children since birth. Rutanen et al. (2014) have highlighted similarities between the two countries regarding the central value of human dignity, the understanding of the child's right to life and full development, and the upholding of the child's right to daycare services before compulsory schooling.

In Brazil, ECEC is governed by the Child and Adolescent Statute (ECA, Ministry of Education of Brazil 1990) and the Law of General Guidelines for Education n. 9.394196 (Ministry of Education of Brazil 1996), and this service is to be provided 
by daycare centers ( $0-3$ years old) or pre-primary schools (4-5 years old) under the pedagogical responsibility and budgetary administration of the municipalities (Ministry of Education of Brazil 2006). According to the Brazilian National Curriculum Guidelines for Early Childhood Education, ECEC should provide the conditions to ensure recognition, appreciation, respect, and interaction among children, promoting their integral development and respecting their individual needs (Ministry of Education of Brazil 2010). Like in Brazil, Finnish ECEC is regulated at the national level, but municipalities are responsible for its organization and provision (Act on Early Childhood Education and Care 2018/540). In Finland, ECEC is based on an integrated approach to education and care, the so-called "educare" model. Finnish legislation defines ECEC as a planned and goal-oriented entity of education, nurture, and care, with an emphasis on pedagogy.

However, despite a similar understanding of the role of ECEC in the child's development and recognizing it as a universal right of all children, Brazil and Finland have materialized this service in very distinct ways. While in Finland the participation rate in the fairly equal and homogenous ECEC system is around $75 \%$ among the 3-5-year-olds, in Brazil this figure is still below 50\% (INEP 2016), frustrating the expectations in the National Plan for Education (Ministry of Education of Brazil 2016). Additionally, in Brazil, the entire educational system is plagued by social inequality and inequity, which results in different ECEC services according to locality, income, and race. Albeit it is evident that both nations face different problems, it is also true that they aim to enhance children's participation (Santos 2010; Carvalho et al. 2009) and share the concern to find innovative ways to promote significant learning while avoiding "schoolification" of ECEC. There is a significant investment on reviewing internal policies and practices (Hietamäki et al. 2017; Simões and Lima 2016), which by culturally contextualizing international debates on ECEC, Brazil and Finland have evidenced their commitment to diminish social inequalities by investing in quality education. Therefore, the rationale of choosing these countries is that we recognize and value the distinct cultural characteristics of Brazil and Finland, interpreting them as an element that can enrich the investigation of a complex phenomenon such as the learning experiences of children.

\section{Methodological Approach}

This study adopted an abductive process of reasoning (Okasha 2002) in which scientific thinking prioritizes information that comes from data rather than seeking to confirm a specific theoretical hypothesis. Furthermore, we base the analytical process on the principles of qualitative methodology presented by González-Rey (2009). These principles focus on the study of subjectivity by considering the constructive-interpretative and singular character of the production of scientific knowledge and by understanding research as a dialogical process. The constructive-interpretative methodology allows a nonlinear relation with the field of research and its participants. Data are not taken from the participants, but rather produced and interpreted considering reflections, dialogs, and an entire communication system that 
grants centrality to those involved in the research (González-Rey 2014). Thus, we allow for the non-standardized in the context of research, emphasizing the quality of the information produced and placing the researcher in the midst of interpretations. In the following sections, we outline the way in which we undertook this methodological path.

\section{Participants}

The participants consisted of forty 3-6-year-old children from one ECEC school in each country. Participants were randomly selected from a total of 225 and 52 children in the Brazilian school and the Finnish daycare center, respectively. Children were only included if they manifested a wish to participate in the study and if their parents consented to their participation. It is important to add that both ECEC schools had children from different social backgrounds, which resulted in a heterogeneous group of children. In the Brazilian context, cultural diversity is a characteristic feature of the society, and the different socioeconomic backgrounds of the children added to this heterogeneity. In the Finnish context, diverse economic backgrounds contributed to the heterogeneity, in this case, because there has been a significant increase of foreigners in the educational system. Thus, the sampled groups included children from different classes: middle, low-income, and upper-middle.

\section{Ethical Considerations}

The ethical committee of the Federal University of Uberlândia (CAAE 43646815.2.0000.5152) and municipal authorities approved this study. In line with the guidelines of responsible and ethical research with human beings, data containing the real names of the children or the school were kept confidential. Children's names were replaced by fictitious ones, and pictures containing images of people (e.g., other children, teachers, or staff members) were altered to prevent identification. To ensure that the parents of all children involved were aware and supportive of the research, formal written consent agreements were obtained. Additionally, children were consulted and took part of the study only if interested. They were also able to leave the study whenever they wanted.

\section{Data Collection}

Participants were divided into three groups of six to seven children according to their age (3-4-year-olds; 4-5-year-olds; and 5-6-year-olds) for the discussion groups. Data were then collected by a two-step process, which was applied in both settings similarly. The first step explored children's representation of the connections they created between learning and the spaces that they used, constructed, and lived in the school. This procedure consisted of a group session in which children were invited to talk about what it meant to learn in school, and immediately after to walk around the school and photograph the spaces, objects, people, or situations that they thought 
were related to learning. Photographs have been used in sociological (Allen 2012), psychological (Blackbeard and Lindegger 2007), and educational studies (Harcourt and Mazzoni 2012; Loughlin 2013). They are a powerful tool to capture individual representation, enabling, for example, children to present their views through a means of other than just language (Clark 2005; Cook and Hess 2007; Einarsdottir 2005). During the walk around the school, in pairs, children could autonomously use the camera (provided by the researchers) and were permitted to take as many pictures as they liked (67 in the Brazilian groups and 250 in the Finnish groups). Later, the researchers organized these photographs and excluded the ones that had exactly the same content. Thus, each group from each country had about 10-30 pictures.

In the second step, children's reflections about the learning processes and the contents in those particular spaces photographed by them were sought. In this case, photography was used as a tool to establish a dialog with the children, contextualizing the content of their perceptions, and allowing their voices to be expressed. For this step, researchers conducted a group interview session and used the chosen pictures of each group to initiate the discussion. They guided the reflections with using questions such as: Why did you choose this picture? Where are you? What happens when you are in this place? What can you do in these places? Do you think you are learning something when you are there? What would that be? Who are you with when you are learning?

The interviews with the children were audiotaped and transcribed for the content analysis. All data collection procedures were administered to each group of children separately; and it is important to note that the same research protocols and instructions were used in both countries.

\section{Analysis}

The data collection generated two different sets of material for analysis: children's pictures and the transcripts of children's reflective narratives. We focused only on the most obvious meaning of the pictures, without applying any technical or artistic measurements (Thinker 2013). Through this process, we created a map of children's representations in each age group according to the following categories that emerged from the analysis process of the content of the pictures: (a) inside/outside and (b) object, person, place, and scene (i.e., place with people doing something).

Next, content analysis was used to examine the interview transcripts of all the groups. Thought the study used an abductive approach, questions were used as (pre) structured topics to guide the interview. The dimensions for the analysis were as follows: (a) Where I learn; (b) What I learn; (c) When I learn, and (d) Who I learn from/with. Thus, the coding process involved identifying elements that were directly related to these themes. The results were grouped into four categories that emerged from the content analysis, revealing how children perceive their learning experience in those particular school spaces: objects, action, significant others, and cultural practices. 
To ensure thoroughness in coding, both materials were analyzed first in the country of origin (Brazilian data analyzed in Brazil and Finnish data in Finland), and subsequently, by the partner country. However, for juxtaposition of the data and cross-cultural understanding of the phenomenon, we added another phase in which the whole corpus was discussed by a multicultural group of researchers. In this process, we analyzed divergent results and incorporated translations of cultural elements that were essential to contextualize and understand each dataset. While crosscultural comparison only shows differences and similarities, juxtaposition allows their integration, revealing the core elements of the phenomenon.

\section{Results}

The first steps of the data analysis resulted in a map of children's representations (see Table 1). This map shows how the children in each age group in each country represented the relations between the learning experience and school space with their pictures.

Brazilian children represented their learning experiences with pictures that chiefly focused on objects or places. Pictures of objects included swings in the playground, stairs, taps in the toilet, books from the library, plants from the greenhouse, and decorations in the classroom. The places registered by the children covered not only their classroom, playground, and yard but also the cafeteria and the green area that surrounded the school, which the children referred to as the "magic forest." This variety of images suggests that the children understand their learning processes as something that also happens outside of the traditional classroom environment; the processes do not relate exclusively to academic activities structured by the teacher.

Finnish children also represented their learning experiences by mainly focusing on objects and places. Indoor places registered by the children included entrance halls, toilets, corridors, and rooms for various activities, such as sleeping, gymnastics, handcrafts, and morning circles. Outdoor places represented in the pictures consisted of the playground and the yard. Among the pictures of objects were chairs,

Table 1 Summary on the content focus of children's photographs

\begin{tabular}{lllllll}
\hline Age group & Inside spaces & Outside spaces & Objects & Persons & Places & Scenes \\
\hline G1-Brazil & 2 & 12 & 5 & 1 & 7 & 1 \\
G2-Brazil & 4 & 6 & 2 & 0 & 5 & 3 \\
G3-Brazil & 8 & 6 & 3 & 0 & 6 & 5 \\
G1-Finland & 29 & 2 & 6 & 3 & 20 & 2 \\
G2-Finland & 26 & 3 & 7 & 0 & 21 & 1 \\
G3-Finland & 18 & 7 & 9 & 0 & 14 & 2 \\
\hline
\end{tabular}

Three groups of six to seven children participated in the study from each country and were grouped within the research for the discussions according to their age (3-4-year-olds; 4-5-year-olds and 5-6-yearolds) 
tables, beds, smart boards, books, materials for handcrafts and morning circle activities, letters and written rules on the wall, shoes, and coat racks. In addition, objects used in physical exercises such as outdoor slides and indoor ladders were captured. Pictures taken by the 3-year-old children, to represent their learning experience, also featured other people (children taking photos with an iPad). In contrast, the pictures taken by 6-year-old children more frequently featured various pedagogical objects such as letters and smart boards. This variety of elements photographed conveys that the children understand their learning as something that can happen everywhere in the daycare center, in the material spaces available to them.

Further, the analysis of the interview transcripts yielded four response categories that summarized how children perceived their learning experience. We represent these categories in Fig. 1, and in the following section, we use them to exemplify children's perceptions along with excerpts from the original datasets.

\section{Category 1: Objects}

Objects often appeared in the children's pictures, and their narratives revealed the connection between the learning experiences and the objects in school, both indoors and outdoors: "This way... hmm, like we are going to slide and then to swing and ... with one foot go bouncing all the way to the floor." (Anna, 5 years old, referring to the pictures with the slides). Additionally, children referred to their learning experiences when using the various tools designed to create a child-friendly pedagogical environment, such as slides, smart boards, or specific elements from the school infrastructure, such as stairs and water taps in the toilet: "Climb to the ladder and ... jump off it and then I don't know ... Still... Oh well... I'm going to do such balancing things, I do not remember what they are called." (Terhi, 4 years old, referring to the picture of the ladder).

These narratives showed how the objects that compose different places of the school environment are part of the whole, and when in contact with these objects,

Fig. 1 The four categories that emerged from the data, which revealed how children perceive their learning experiences

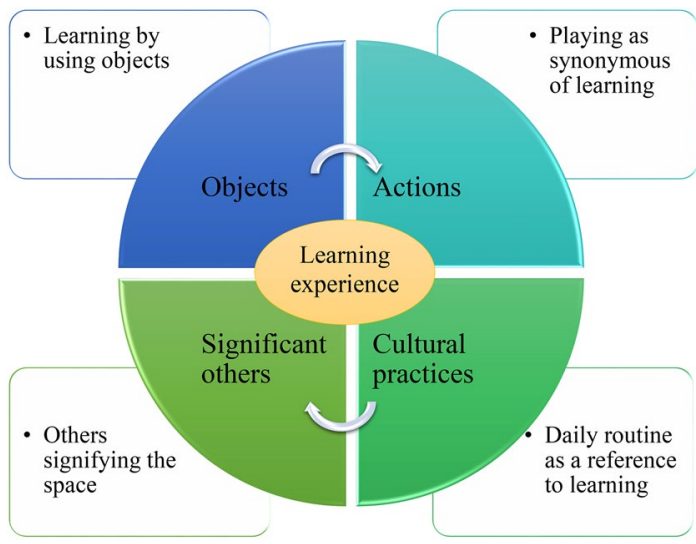


each child can signify them according to their own singular experience, which on many occasions can transform the functionality of the object. For example, children from G2-Brazil represented a learning situation by taking a picture of a pole used to hold up a volleyball net in the yard. During the interview, the children described the object as the pole that they used to learn how to climb: “... It is the stick we climb, there we learn how to climb on" (Maria Clara, 4 years old); "We learn to go up and down... yes... there is a stick that we climb" (João Paulo, 4 years old); "It is a place of many friends" (Jennifer, 4 years old). Thus, the objects that compose the different spaces of the school are signified in a singular way, depending on how the children produce experiences when in contact with them.

Another important aspect of this category concerns the quality or the characteristics of the material environment. At no point did the children refer to the appearance of the objects or places (e.g., an ugly or damaged toy, old furniture, or a beautiful room). The possibilities that a particular space afforded were significant from the viewpoint of children's learning experience. In many situations, the children described the meaning of a learning experience based on what they were able to do with that object or in that specific place: "I think that I am learning to do many sprints because when we run there we take such a long path; this lane is huge" (Arthur, 6 years old, referring to the picture of the running track in the yard).

It was also evident that the children expressed and connected various meanings to the same objects and places. The following discussion between 6-year-olds and their teacher illustrates how the hall was interpreted both as a space for constructing activities and as a space to learn the school's social rules:

Teacher: What does this picture mean?

Rafael: It is the hall.

Teacher: The hall? And, why have you taken a photo of this place?

Rafael: Because here you had, there you had the math problems, and then we build with Lego and other things.

Teacher: The girls could also tell. You have taken pictures from same places. What have you learned here?

Alina: We have learned that you can't yell there. (Children from the six-yearold age group, referring to the picture of the hallway with the walls covered with activities)

\section{Category 2: Action}

This category refers to learning experiences perceived by children from the actions they execute during their school routine. This category was identified by the verbs children used to describe their learning situations, and these verbs typically used when the children described pictures containing scenes - a combination of the place and the people present (e.g., a classroom full of children during playtime).

Here I learned to put shoes on. (Elias, 5 years old, referring to the picture of the entrance to the classroom). 
I learned to wet myself in the water and take a shower. (João Paulo, 5 years old, referring to the picture of children in the showers).

When I learned to eat there, I learned how to use the fork and the knife ... and still... when... to go to eat. (Tomi, 5 years old, referring to the picture of children in the dining room).

And here I have taken a photo of an ornamental leaf... I have learned to work at the hobby and to make an ornament from leaves. (Laura, 5 years old, referring to the picture of her own, handmade leaf ornament).

The actions described by the children as learning situations were diverse-from descriptions directly related to the systematization of formal school knowledge (reading a book, counting, etc.) to situations that were associated with being at school and exploring the space (learning how to behave in the classroom or how to walk in the school's corridors). Interestingly, play activities were similarly represented in both country's datasets, indicating that children can identify learning in play.

In this particular category, most of the differences in the children's descriptions were related to the country of origin. Brazilian children mainly expressed their perception of learning by referring to actions associated with daily collective and free activities: "I learned to slide" (Miguel, 5 years old, referring to the picture of the slide); "I learned to choose a juice" (Eloah, 5 years old, referring to the picture of the cafeteria). On the other hand, Finnish children described actions that were more related to systematized school activities: "I am... I am learning in the morning circle to count to twenty" (Laura, 5 years old); "I have also learned in the morning circle how to say the days" (Matti, 4 years old); and "I have learned to look at the pictures: these pictures are nice, though I don't read." (Iiro, 4 years old).

Generally, the children's narratives about their learning through actions were shaped by a sense of time, highlighting the presence in time and learning as an instantaneous, experimental, sensitive, and sensory experience. The descriptions showed a connection between learning and the novelty of doing something new, movements that involve others, and different opportunities to experience in space-time structure.

\section{Category 3: Significant Others}

Most of the pictures taken by the children mainly represented the physical environment, such as indoor and outdoor places and the tools found in these spaces. It is noteworthy that the place for children's learning is mainly the space where everyone is together: the classroom, the playground, the sandbox, and other spaces photographed and referred to by the children. However, interestingly, when the children reflected on the pictures of places and objects, they often referred to the people involved in the learning situations in these places. Thus, peers had the most significant role in the children's narratives; they were spoken of as having multiple roles (e.g., the role of a person who teaches or one who guides actions) and different positions (e.g., as a proponent or a follower): 
There (referring to the picture of the yard) is a day when I taught the girls to run faster. (Maria Eduarda, 5 years old).

She (referring to the peer) also teaches how to dance, isn't that right, Maria Eduarda? (Ana Luiza, 5 years old).

The results in this category reveal a co-learning environment and an understanding of learning experience in which children recognize peers as models worth observing either in free activities or in adult-driven situations, such as morning circles or group discussions:

I draw so badly, but so badly that my friends teach me how to do it right. (Maria Laura, 6 years old).

He takes my hand and I take his, then I slide. (Miguel, 5 years old, explaining how he learned with a peer how to use a slide).

Laura (5 years old): I am...I am learning about the morning circles... how to count to twenty.

Teacher: Ahaa! Was there anyone with you when you learned?

Laura: All my friends.

The role of the adult was mentioned more frequently (twice as often) by the 6-year-old groups; they related it mostly to someone who taught the rules. The word "no" was commonly used in association with the school's social rules-to explain what they could not do in each specific environment, such as "I learnt not to throw sand at anybody with the teacher" (Isaias, 6 years old, referring to the rules in the sandbox). The only time that the children explicitly associated the teacher with content they learned was when reflecting on a picture of the yard where the gymnastics class was usually conducted. In this image, the teachers appeared to be explaining what the children were going to do: "Teacher explains how we are going to play" (Ana Luiza, 6 years old); or showing how the activity is done, "When I am with L. (teacher), I learn to do some exercises" (Ana Vitoria, 6 years old).

This category revealed that the children from all age groups perceived their learning experience at these two schools as a process that occurred with and through other people, highlighting the role of peers as partners. The places or the objects in the pictures also represented learning situations that were directly related to the relationships established with each space of the school. Thus, the meaning of the learning experience was only expressed when the children talked about how these moments were constituted and who composed the space.

\section{Category 4: Cultural Practices}

In this study, cultural practices refer to all the interactions and activities that organize and constitute school life. While describing their learning experiences, children named some of these specific activities. Thus, this category captures children's perceptions of learning related to daily school practices, such as morning circles, playground time, teacher-directed activities, dressing up in the entrance hall, and having 
breakfast/lunch. The children connected certain learning experiences to specific places in which the daily practices occurred, indicating that they had clear and different expectations of learning, depending on specific practices and spaces. This is evident in the following dialog between the teacher and Anni, 5 years old:

Teacher: Let's see from here. What place is this?

Anni: From the morning circle.

Teacher: Yes. And what can you learn there?

Anni: You learn to calculate and... Then to say the weekdays.

Teacher: Then, what is this place?

Anni: The resting room.

Teacher: What do you think you could learn here?

Anni: Well, there you can learn the "by steps" lesson, because, you learn different emotions there.

Teacher: Yes, you have gone through that. And this place is?

Anni: The middle room.

Teacher: Yes. And what do you learn here?

Anni: There you learn how to do paper crafts, and then, well, to do finger marking.

Teacher: We have done that a lot.

Interestingly, in both the Finnish and Brazilian data, we noted that this connection between content, practice, and place becomes clearer as the children get older. By referring to certain practices and places, the children also referred to the norms or rules that framed the learning situations, and thus provided a context for the learning experiences. Expressions such as "we have learned that we can't yell there," (Isaias, 6 years old, referring to the picture of the corridor with the activities of the children displayed on the walls of the school entrance) reveal that the children internalized social behavioral rules as the content of learning and associated them with a certain practice of the school routine. Even though the teachers and children constructed the rules jointly, and therefore the rules appeared contextualized in daily practice, the adults did not expect these practices to serve as a context for learning situations among the children. In the following excerpt, the teacher makes a conceptual difference between learning and behaving, and by doing so, she also produces a culturally accepted way of understanding learning:

Teacher: ... well, do you learn any new things or issues in this morning circle? Lenna: that you have to sit on the bench and have to be silent

Teacher: But are you learning something? That is quite about behavior.

Lenna: I learned how to calculate. (Lenna, 6 years old)

The flow of the discussion reveals how the child changes her own interpretations and accommodates the teacher's understandings by referring to calculations as the focus of learning. The discussion illustrates the differences between the child's and teacher's understanding about the focus of learning and the teacher's powerful position in defining how learning is conceptualized. These values, rules, 
and the power relation between the teacher and the child also appeared in different kinds of cultural regulation, where institutional orders are negotiated between the teacher and children.

\section{Discussion}

The starting point of this study was recognizing the importance of children's perceptions of their own learning experiences. We also assumed that to explore these perceptions, it was important to understand learning as a fundamentally social phenomenon (Vygotsky 1979) that is intrinsically linked to a specific social context, space, and time. It is important to remark that the questions that guided the discussions also situate children's reflection, affording or constraining the themes discussed. These premises framed the investigation of how children perceive their learning experiences in ECEC and supported how we interpreted the results.

The study showed that the children's perceptions of learning are intimately connected to how they explore objects and places, indicating that children create opportunities to freely construct knowledge based on their appropriation and multiple uses of objects. The relationship that children form with the objects in the school context was an aspect that motivated us to consider elements that are not necessarily part of the teachers' pedagogical resources (e.g., the taps in the toilet, shoes, or stairs). Each child signified these objects according to their own singular experience, which, on many occasions, involved transforming the functionality and purpose of the objects and applying of new meanings according to space and time. This shows that children not only reproduce meanings but produce it; they do not just adapt to the modification and (co)construction of social values and norms, but also influence them. This finding supports previous research that has shown how children are active co-constructers of culture (Corsaro 2003, 2005).

Further, children also perceived their learning experience as the actions that they executed in the school space, and they identified these acts in progress as the content of learning. This acknowledgment of action as a learning experience implies that, for children, the focus of the learning process is not learning about something (e.g., about numbers, mathematics), but rather learning how to execute something (e.g., counting from one to ten). The importance of empirical experiences for the construction of knowledge in the early years has been heavily discussed within the historical-cultural theoretical framework since Vygotsky's $(2007,2009)$ work. Elements such as movement, pretend play, and role-play have been the most significant activities for preschoolers (Amparo et al. 2006), and numerous works from the disciplines of psychology, education, and sociology address this topic and discuss its relation to children's development. A salient feature of this study is that it asks the children to express the empirical grounds of their learning processes by giving them an opportunity to do so. Listening to the children is thus emphasized here as a fundamental methodological approach to organize pedagogical work with children, irrespective of their cultural and social background.

Despite being exposed to all sorts of material for teacher-directed activities, children represented their learning experiences through pictures of objects, 
places, and scenes that were related to their free process of knowledge construction. Their narratives evidenced that learning is always negotiated with those who share that particular frame of time and space. Therefore, when identifying what elements children use to express their learning experiences, it is important to consider that children learn according to a timeframe determined by themselves, regardless of the intentions of adults.

Through the children's narratives, we identified tactics (Certeau 1994) to use school time and space in a singular dimension. While children recognize the limitations of time placed by adults, they nevertheless create their own daily schooling by touching and modifying these limitations via new actions, relationships, and even new possibilities to live the experience in space-time. When the learning space is an arena for tactics, it can also be seen as a Thirdspace (Soja 1996) and heterotopia (Foucault 1967). For Soja, heterotopia is an example of the Thirdspace. In open social spaces, children can negotiate alternative orders of learning and become agents of learning. The learning space is undefined-a space of tactics and a place to explore one's identity outside defined learning routines (Kupiainen 2013). Thirdspace and heterotopia are alternative social ordering that help realize creative practices and construct learning in spatializing processes with peers and cultural objects (Soja 1996). In this sense, a learning space is then a product of different subjectivities, relationships, and practices (Comber 2016), constructed in relation to other surrounding places and spaces, communities, and cultures. These relations are important and give directions to learning and teaching, and by understanding the learning space as a social product (Soja 1996), we recognize how children experience their learning across space in different ways.

Interestingly, in both the Finnish and Brazilian groups, the appearance (e.g., the color of walls and details of toys or costumes) and the characteristics of objects and places (e.g., plastic or fabric dolls, wooden or plastic playgrounds) were never mentioned. This observation suggests that for the children, the most significant elements of objects and places are the access to them and the opportunity to explore them freely, and we recognize that the nature of the questions that children were asked in the interviews may not have elicited specific reflections on the appearance of objects.

When we move from debating children's perceptions and focus on the relations established by children between learning and the space in which they learn in ECEC contexts, the relevance of others (i.e., human beings) in the learning experience becomes evident. The children revealed that peers and teachers signify the school space and are an essential part of the learning experience; thus, they express an understanding of learning as a collective process. Even when children refer to specific objects manipulated by them individually, the contextualization of the learning experience occurs by the recognition of the others that shared that situation of learning.

Although teachers inhabit the socially recognized role of "the one that teaches," they did not seem to occupy a place of privilege in the children's experiences in either country. In fact, that position belonged to the peers. Previous studies (Ferreira 2017; Ferreira et al. 2016) have arrived at similar findings, showing that even when children have an adult by their side, they can still place peers as 
the reference point for different activities. Peer culture is mainly constructed by the sharing of meanings and the (co)construction of play repertoire between children (Corsaro 2003, 2005). In this study, the children not only referred to peers as a reference point but also sought their voluntary and intentional assistance for learning how to do something. Hence, when reflecting on their learning experiences, the children revealed an intentionality that is rarely recognized by adults in peer-learning situations.

Our analysis revealed how the children's narratives of learning were partly influenced by the cultural manuscript of the school. By cultural manuscripts (Tan 2015; Gutierrez et al. 1995), we refer to the cultural values, assumptions, beliefs, and their manifestation in the daily practices of the schools. The national-level regulation and steering documents, as well as broader cultural beliefs, partly influence the cultures of schools. However, each school's culture is constructed by the everyday activities that involve teachers, children, and other staff members. Thus, given that all the described situations and narratives occurred and were constructed in the actual school environment, it is possible to conclude that the school is a space of learning allows the children to construct themselves and other children significantly in the learning process. The school culture does not enforce learning from a futureoriented perspective but allows them to learn in the here and now. In addition, the children are allowed to use both outdoor and indoor spaces as learning spaces.

\section{Conclusion}

The children's narratives showed how learning implies action, doing something to be experienced in the "here and now," contextualized in their immediate interest. This is a vital aspect of how the children in this study represented and constructed the meaning of their learning experiences as independent work, or as work that is different from an adult's teaching-learning intention. Children are agents of learning as well as producers of their own learning environment within the ECEC settings (Vuorisalo et al. 2015). When we understand learning as intertwined with material objects, actions, significant others, and cultural practices in social spaces-as relational and constructed in individual experiences - we can also see the learning environment as subject to reconstruction. This means that learning is embedded in the immediate relationships of surrounding materiality, teachers and peers as well as shaped by cultural practices, communities, and experiences of individuals (Comber 2016).

The implications of these finding relate to the possibility open for children to be invited to imagine, design, and make material changes in their learning environments in ECEC settings, as they recognized their own competence for learning, exploration of places, manipulation of objects, and transformation of their surroundings to potentiate new experiences. The study supports the argument that children must be featured as protagonists in their learning processes. This study utilized the opportunity to listen to children's voices in two different countries, and given the results, we expect that teachers, experts in education, and other professionals 
involved in developing alternatives to potentiate learning may glean ideas to reflect upon their understanding of children's learning, as well as the role of peers and the various spaces within that learning.

Acknowledgements The study was conducted with the financial and infrastructure support from the Federal University of Uberlândia and Tampere University.

\section{Compliance with Ethical Standards}

Conflict of interest We here state that throughout the development and finalization of this work there were no situations involving financial and personal relationships that could inappropriately influence (bias) this work. Therefore, we declare no conflict of interest.

Open Access This article is distributed under the terms of the Creative Commons Attribution 4.0 International License (http://creativecommons.org/licenses/by/4.0/), which permits unrestricted use, distribution, and reproduction in any medium, provided you give appropriate credit to the original author(s) and the source, provide a link to the Creative Commons license, and indicate if changes were made.

\section{References}

Act on early childhood education and care 2018/540. Accessed September 21, 2018. Retrieved from https ://www.finlex.fi/fi/laki/alkup/2018/2018/540.

Allen, Q. (2012). Photographs and stories: Ethics, benefits and dilemmas of using participant photography with Black middle-class male youth. Qualitative Research, 12(4), 443-458.

Amparo, D., Pereira, M. A., \& Almeida, S. (2006). O brincar e suas relações com o desenvolvimento. Psicologia Argumento, 24(45), 15-24.

Blackbeard, D., \& Lindegger, G. (2007). Building a wall around themselves: Exploring adolescent masculinity and abjection with photo-biographical research. South African Journal of Psychology, $37(1), 25-46$

Burger, K. (2015). Effective early childhood care and education: Successful approaches and didactic strategies for fostering child development. European Early Childhood Education Research Journal, 23(5), 743-760.

Carvalho, A. M. A., Muller, F., \& Sampaio, S. M. R. (2009). Sociologia da infância, psicologia do desenvolvimento e educação infantil: diálogos necessários [Sociology of childhood, developmental psychology and early childhood: Necessary dialogs]. In F. Muller \& A. M. A. Carvalho (Eds.), Teoria e prática na pesquisa com crianças, diálogos com William Corsaro (pp. 189-208). São Paulo: Cortez.

Certeau, M. (1994). A Invenção do Cotidiano: Artes de fazer. Petrópolis: Vozes.

Clark, A. (2005). Listening to and involving young children: A review of research and practice. Early Child Development and Care, 175(6), 489-505.

Colliver, Y., \& Fleer, M. (2016). I already know what I learned: Young children's perspectives of learning through play. Early Child Development and Care, 186(10), 1559-1570.

Comber, B. (2016). Literacy, place, and pedagogies of possibility. New York: Routledge.

Cook, T., \& Hess, E. (2007). What the camera sees and from whose perspectives: Fun methodologies for engaging children in enlightening adults. Childhood, 14, 29-45.

Corsaro, W. (2003). We're friends, right? Inside kid's culture. Washington: Joseph Henry Press.

Corsaro, W. (2005). The sociology of childhood. Beverly Hills: Sage Publications.

Einarsdottir, J. (2005). Playschool in pictures: Children's photographs as a research method. Early Child Development and Care, 175(6), 523-541.

Emilson, A., \& Folkesson, A.-M. (2004). Children's participation and teacher control. Early Child Development and Care, 176(3-4), 219-238.

Ferreira, J. M. (2017). Crianças com déficit intelectual e processos interacionais com pares na préescola: reflexões sobre desenvolvimento [Children with intellectual disability and their interactions 
in pre-school: Discussing about human development]. Doctoral thesis, Faculty of Philosophy and Science, Doctoral Program in Psychology, University of São Paulo.

Ferreira, J. M., Mäkinen, M., \& de Amorim, K. S. (2016). Intellectual disability in kindergarten: Possibilities of development through pretend play. Procedia: Social and Behavioral Sciences, 217, 487-500.

Foucault, M. (1967). Of other spaces, heterotopia (Trans., J. Miskoviec). Accessed February 9, 2018. Retrieved from http://web.mit.edu/allanmc/www/foucault1.pdf.

González-Rey, F. (2009). Questões teóricas e metodológicas nas pesquisas sobre aprendizagem. In M. A. Martinez \& M. C. V. R. Tacca (Eds.), A Complexidade da Aprendizagem (pp. 123-151). Campinas: Alínea.

González-Rey, F. (2014). Ideias e Modelos Teóricos na Pesquisa Construtivo-Interpretativa. In A. M. Martinez, M. Neubern, \& V. D. Mori (Eds.), Subjetividade contemporânea: discussões epistemológicas e metodológicas (pp. 13-34). Campinas: Alínea.

Goodrich, J. M., Lonigan, C. J., \& Farver, J. M. (2017). Impacts of a literacy-focused preschool curriculum on the early literacy skills of language-minority children. Early Childhood Research Quarterly, 40(3), 13-24.

Gutierrez, K. D., Larson, J., \& Kreuter, B. (1995). Cultural tensions on the scripted classroom: The values of the subjugated perspective. Urban Education, 29(4), 410-442.

Harcourt, D., \& Mazzoni, V. (2012). Standpoints on quality: Listening to children in Verona, Italy. Australasian Journal of Early Childhood, 37(2), 19-26.

Helal, S., \& Weil-Barais, A. (2015). Cognitive determinants of early letter knowledge. European Early Childhood Education Research Journal, 23(1), 86-98.

Hietamäki, J., Kuusiholma, J., Räikkönen, E., Alasuutari, M., Lammi-Taskula, J., Repo, K., Karila, K., Hautala, P., Kuukka, A., Paananen, M., Ruutiainen, V., \& Eerola, P. (2017). Varhaiskasvatus ja lastenhoitoratkaisut yksivuotiaiden lasten perheissä [Solutions on early childhood education and care in families with one-year-old children]. National Institute for Health and Welfare (THL). Discussion paper 24/2017. Helsinki, Finland.

INEP. (2016). Sinopse Estatística da Educação Básica. Brasília: Ministério da Educação e Cultura.

Kupiainen, R. (2013). Media and digital literacies in secondary school. New York: Pete Lang.

Landry, S. H., Zucker, T. A., Williams, J. M., Merz, E. C., Guttentag, C. L., \& Taylor, H. B. (2017). Improving school readiness of high-risk preschoolers: Combining high quality instructional strategies with responsive training for teachers and parents. Early Childhood Research Quarterly, 40, 38-51.

Larkin, S. (2010). Metacognition in young children. Oxon: Routledge.

Larrosa, J. B. (2002). Notas sobre a experiência e o saber de experiência. Revista Brasileira de Educacão, 19, 20-28.

Loughlin, J. (2013). How photography as field notes helps in understanding the building the education revolution. Austrian Education Research, 40, 535-548.

Ministry of Education of Brazil. (1990). Childhood and Adolescent Statute: Law n. 8.069, 13th of July 1990. Brasília: Chamber of Deputies.

Ministry of Education of Brazil. (1996). Law 9.394, 20 of December 1996, of General Guidelines for Basic Education. Brasilia: National Congress.

Ministry of Education of Brazil. (2006). Guidelines for early childhood institution infrastructure. Brasília: Secretary of Basic Education SEB.

Ministry of Education of Brazil. (2010). National curriculum guidelines for early childhood education. Brasília: Secretary of Basic Education, SEB.

Ministry of Education of Brazil. (2016). National plan for education: Guidelines for monitoring and evaluation of municipal education. Brasília: Secretary of Basic Education, SEB.

Okasha, S. (2002). Philosophy of science: A very short introduction. England: Oxford University Press.

Pálmadóttir, H., \& Einarsdóttir, J. (2016). Video observations of children's perspectives on their lived experiences: Challenges in the relations between the researcher and children. European Early Childhood Education Research Journal, 24(5), 721-733.

Powell, M. A., Graham, A., Taylor, N. J., Newell, S., \& Fitzgerald, R. (2011). Building capacity for ethical research with children and young people: An international research project to examine the ethical issues and challenges in undertaking research with and for children in different majority and minority world contexts, Dunedin. Dunedin: University of Otago Centre for Research on Children and Families. 
Rutanen, N., Amorim, K. S., Colus, K. M., \& Piattoeva, N. (2014). What is best for the child? Early childhood education and care for children under 3 years of age in Brazil and Finland. International Journal of Early Childhood, 46(2), 123-141.

Sant'Ana, R. B. (2010). Criança-sujeito; experiências de pesquisa com alunos de escola pública. In M. P. R. de Souza (Ed.), Ouvindo Crianças na escola: Abordagens qualitativas e desafios metodológicos para a psicologia (pp. 23-50). São Paulo: Casa do Psicólogo.

Santos, A. A. (2010). Construindo modos de conversar com crianças sobre suas produções escolares [Talking to children about their school activities]. In M. P. R. Souza (Ed.), Ouvindo crianças na escola (pp. 203-228). São Paulo: Casa do Psicólogo.

Simões, P. M. U., \& Lima, J. B. (2016). Infância, educação e desigualdade no Brasil [Childhood, education and social inequality in Brazil]. Revista Iberoamericana de educación, 72, 45-64.

Soja, E. (1996). Thirdspace: Journey to Los Angeles and other real-and-imagined places. Cambridge: Blackwell.

Tan, C. (2015). Education policy borrowing and cultural scripts for teaching in China. Comparative Education, 51(2), 196-211.

Thinker, P. (2013). Using photographs in social and historical research. Los Angeles: Sage Publications.

Trautwein, C., \& Goncalves, T. (2010). A dor e a delícia de entrevistar crianças na construção de um procedimento [The gain and the pain to interview children within the construction of a procedure]. In M. P. R. de Souza (Ed.), Ouvindo Crianças na escola: Abordagens qualitativas e desafios metodológicos para a psicologia (pp. 257-278). São Paulo: Casa do Psicólogo.

Vuorisalo, M., Rutanen, N., \& Raittila, R. (2015). Constructing relational space in early childhood education. Early Years: An international journal of research and development, 35(1), 67-79.

Vygotsky, L. S. (1979). Mind in society: The development of higher psychological process. Cambridge: Harvard University Press.

Vygotsky, L. S. (2007). A formação social da mente: o desenvolvimento dos processos psicológicos superiores. [Mind in society: The development of Higher Psychological Process]. São Paulo: Martins Fontes.

Vygotsky, L. S. (2009). Imaginação e criação na infância [Imagination and creativity in childhood]. São Paulo: Ática.

\section{Affiliations}

\section{Juliene Madureira Ferreira ${ }^{1}$ D Kirsti Karila $^{2}$ - Luciana Muniz ${ }^{3}$. Paula Faria Amaral ${ }^{3}$ - Reijo Kupiainen ${ }^{4}$}

Kirsti Karila

kirsti.karila@uta.fi

Luciana Muniz

Luciana.muniz@ufu.br

Paula Faria Amaral

paula.faria@ufu.br

Reijo Kupiainen

reijo.p.kupiainen@ntnu.no

1 Faculty of Education and Culture, Tampere University, Åkerlundinkatu 5, Office 509 - VIRTA Building, 33014 Tampere, Finland

2 Faculty of Education and Culture, Tampere University, Åkerlundinkatu 5, Office 303 - VIRTA Building, 33014 Tampere, Finland

3 Department of Early Childhood Education, Teacher Training School, Federal University of Uberlândia, Rua Adutora São Pedro 41, Uberlândia, MG CEP: 38400-785, Brazil

4 Norwegian University of Science and Technology, Trondheim, Norway 